\title{
\begin{tabular}{l|l} 
UNU-WIDER & 30 rears O F RESARCH \\
Un
\end{tabular} FOR DEVELOPMENT
}

WIDER Working Paper 2015/021

\section{Private returns to education for wage-employees and the self-employed in Uganda}

Susan Namirembe Kavuma, Oliver Morrissey, and Richard Upward*

February 2015 
Abstract: The paper investigates the differences in private marginal returns to education between wage-employees and the self-employed in Uganda, using the Mincerian framework with pooled regression models. We use a two-wave household panel to estimate homogenous and heterogeneous private returns to education for both worker types. The study finds similar marginal returns to an additional year of schooling for both worker types. Further, the study finds the returns to educational qualifications are convex for wage-employees and concave for the self-employed. With regard to heterogeneous returns to education, we employ quantile regression models and find returns to education decreasing with quantile for both worker types.

Keywords: returns to education, quantile regression

JEL classification: J24, J310

Acknowledgements: We are grateful to the Commonwealth Scholarship Commission for the financial support, and the World Bank for giving us access to their databank, from which we obtained the data used in this study.

*All authors from the University of Nottingham; corresponding author: susan.kavuma@nottingham.ac.uk

This paper has been presented at the UNU-WIDER Conference on 'Inequality - Measurement, Trends, Impacts, and Policies', held 5-6 September 2014 in Helsinki, Finland.

Copyright (C) UNU-WIDER 2015

ISSN 1798-7237 ISBN 978-92-9230-906-0

Typescript prepared by Minna Tokkari at UNU-WIDER.

UNU-WIDER gratefully acknowledges the financial contributions to the research programme from the governments of Denmark, Finland, Sweden, and the United Kingdom.

The World Institute for Development Economics Research (WIDER) was established by the United Nations University (UNU) as its first research and training centre and started work in Helsinki, Finland in 1985. The Institute undertakes applied research and policy analysis on structural changes affecting the developing and transitional economies, provides a forum for the advocacy of policies leading to robust, equitable and environmentally sustainable growth, and promotes capacity strengthening and training in the field of economic and social policy-making. Work is carried out by staff researchers and visiting scholars in Helsinki and through networks of collaborating scholars and institutions around the world.

UNU-WIDER, Katajanokanlaituri 6 B, 00160 Helsinki, Finland, wider.unu.edu

The views expressed in this publication are those of the author(s). Publication does not imply endorsement by the Institute or the United Nations University, nor by the programme/project sponsors, of any of the views expressed. 
Education plays a key role in economic and social development and many developing countries have used it as a policy tool to reduce poverty. With the objective of reducing poverty and improving human development, Uganda has made substantial investments in education through implementing universal primary education (UPE) in 1997 and the universal secondary education (USE) in 2007, becoming the first country in sub-Saharan Africa (SSA) to introduce the USE. Many studies provide evidence of the positive impact of education on earnings (Schultz 2003; Psacharopoulos and Patrinos 2004) ${ }^{1}$ with returns increasing with level of education in many African countries (Söderbom et al. 2005; Rankin et al. 2010; Leyaro et al. 2012) although this effect diminishes as earnings increase (Patrinos et al. 2006; Kingdon and Söderbom 2007a). Thus the available evidence suggests that investment in education enhances an individual's income and can be instrumental in reducing poverty and promoting income equality.

Conventionally, education plays a key role in determining wages. Many studies provide evidence that more educated workers receive higher wages, work in better paying firms, sectors, and occupations than their counterparts with less education (Schultz 2003; Psacharopoulos and Patrinos 2004). While there is overwhelming evidence of a positive correlation between education and labour market outcomes, scholars are hesitant to draw inferences on the causal impact of schooling on earnings. This is because there is uncertainty as to whether more educated workers earn higher wages due to formal education or due to unobserved characteristics such as the innate ability. The literature presents two major theories to explain differences in labour earnings; human capital theory (Becker 1962) and the signalling theory (Spence 1973). Human capital theory explains wage differentials as a result of an individual's productivity level enhanced by investment in formal education, health, and training, while the signalling theory assumes wage differentials are due to an individual's innate abilities that are signalled by an individual's characteristics which includes educational attainment.

This paper focuses on the effect of human capital variables on earnings as suggested by the human capital theory. The human capital theory posits that education is an investment which improves a worker's productivity and influences future income by raising a worker's lifetime earnings (Becker 1962). The theory relates the worker's knowledge levels to their formal schooling levels implying that more schooling would lead to higher productivity and wages. In this theory, workers acquire education to maximize the present value of lifetime earnings and the private returns are used to explain the demand for different levels of education.

According to the human capital theory, the law of diminishing returns applies to human capital accumulation whereby each successive year of schooling yields less marginal returns. This relationship would suggest a concave schooling-earnings function, implying that initially earnings increase with education at an increasing rate but later at a decreasing rate and eventually may decline. However, most recent studies for African countries (Söderbom et al. 2005; Kingdon and Söderbom 2007a; Quinn and Teal 2008; Rankin et al. 2010) find that returns to education are highest at the upper-end of the education profile. Fasih et al. (2012) note that the convexity of returns to education in developing countries could be due to both supply and demand factors, where the supply of individuals with low education has increased more than their demand and conversely the supply of individuals at the upper education profile has grown slower than their demand.

1 These studies provide a summary of the empirical literature on returns to education. 
In our analysis, we investigate both the homogenous and heterogeneous returns to education separately for wage-employees and the self-employed in Uganda. Many studies have documented high returns to education especially in developing countries (Schultz 2003), however most studies consider only homogenous returns and therefore provide mean returns to education, including earlier studies for Uganda (Appleton 2000, 2001). Nevertheless, the pattern of dispersion of the returns matters and considering only the homogenous returns may mask the effects, yet individuals are not identical but earn different incomes and occupy different positions along the earnings profile. If individuals at the upper earnings profile have higher returns, then further investment in education may worsen the existing income inequality. But if the returns to education are higher for individuals at the lower earnings profile, then further investment in education would reduce income inequality in any country.

Relatively few studies have estimated returns to education in Africa, particularly SSA, and only three for Uganda. Two of the three studies which have investigated private returns at different levels of education in Uganda find returns at primary level higher than at secondary and increasing over time (Bigsten and Kayizzi-Mugerwa 1992 cited in Appleton 2000; Appleton 20012). The third study by Appleton and Balihuta (1996 cited in Appleton 2000) found returns to education increasing with level of education and highest at university. Therefore the available evidence for the pattern of returns to education along the education profile in Uganda is mixed and this study seeks to provide more evidence using most recent data; the 2005/06 and 2009/10 panel survey data (World Bank 2014a, 2014b) and disaggregating it by worker type. Further none of these studies investigates heterogeneous returns to education which we address in this paper.

Our motivation for this study is to estimate the returns to education for the self-employed that form the largest proportion of Uganda's labour force (two-thirds), a group not previously covered in studies for Uganda. Few studies on African countries have estimated returns to education for the self-employed because of data limitations. As the self-employed are effectively synonymous with informal paid employees in Uganda, they form a large proportion of the working poor and thus constitute a target group for poverty reduction strategies. This paper addresses the following research questions: Do private returns to education for wage-employees differ from the returns to the self-employed? What is the shape of the education-earnings-profile for the two worker types? What is the trend of private returns to education over time for both workers? What is the pattern of private returns to education along the earnings distribution for both worker types?

The following section briefly discusses related literature to this study. The theoretical framework and empirical strategy used are in Sections 3 and 4, respectively. In Section 5, we describe the data sources and display the descriptive statistics, and a discussion of the results follows in Section 6. Finally, we summarize and state policy implications for our findings in Section 7.

\section{$2 \quad$ Literature review}

Studies which analyse the returns to education typically adopt the Mincerian framework (Card 2001; Appleton 2001; Psacharopoulos and Patrinos 2004; Girma and Kedir 2005; Kingdon and Söderbom 2007a, 2007b) based on the human capital theory. The basic model consists of a semi$\log$ linear function regressing log earnings on years of schooling (which measures the human capital acquired in formal education) and experience (which measures the human capital acquired

\footnotetext{
2 Appleton finds such results for the 1992 data but obtains the reverse for the 1999/2000 survey data.
} 
in employment). ${ }^{3}$ The parameter estimate on the years of schooling is referred to as the marginal rate of return which gives the approximate percentage change in earnings per extra year in education. Since the earnings-schooling relationship is concave, each additional year of schooling should yield lower marginal returns.

There are two problems encountered in estimating returns to education; endogeneity, and selection bias. The endogeneity problem is caused by the workers' unobserved ability (the error term) systematically correlating with both the independent variables and the dependent variable (earnings). Therefore, the ordinary least squares (OLS) results would be biased representing a correlation between ability on one hand and education and earnings on the other, instead of the casual effect of education on earnings. When the variable of interest is endogenous, then the researcher may not establish the causal relationship and may require use of an instrumental variable that is correlated with the endogenous variable (schooling), but uncorrelated with unobserved ability. Most studies deal with the endogeneity problem by estimating returns to education using instrumental variable techniques such as the two-stage least squares (2SLS) and the control function (Card 2001; Heckman et al. 2006; Kerr and Quinn 2010; Rankin et al. 2010; Leyaro et al. 2012). All these studies find a downward bias in OLS estimates of returns to education. Heckman et al. (2006) note that the results need to be interpreted with caution, since the instrumental variable estimators do not estimate the average causal effect but instead measure the local average treatment effect (LATE): this estimates the returns for individuals induced to vary their schooling level by the change in the instrument. These individuals may not have the same rate of return to education as the average individual.

Selection bias arises from estimating the earnings function on separate sub-samples which may not be a random draw from the population. This is because we only observe earnings for those who have a job which is normally a non-random subsample of all those who received education. To correct for selection bias, studies have used the Heckman two-stage model that first estimates the probit model for selection into employment or occupation to derive the selectivity term in the earnings function (Kingdon and Söderbom 2007a; Rankin et al. 2010; Leyaro et al. 2012).

The estimates for returns to education vary from one study to another. The general observation is that the estimates for developing countries (8-17 per cent) are higher than for developed countries (6-7 per cent), although most studies may not be directly comparable because they include different variables in the model and employ different estimators. This difference in returns to education is an empirical question, but can be attributed to differences in levels of educational attainment and the relative demand for workers with different educational attainment in the respective countries. Recent studies which have analyzed returns to education in SSA mostly find a convex education-earnings relationship. Examples include Rankin et al. (2010) for urban workers in Ghana and Tanzania for mid-2000s, Kingdon and Söderbom (2007a) for Ghana in 1998-99, Sandefur et al. (2006) for urban workers in Ghana and Tanzania (2004 and 2005) and Ethiopia (1994 and 2000), or Kerr and Quinn (2010) for Tanzania using cross section data for 2001 and 2006.

In Uganda's case, Appleton (2001) using household survey data for 1992 and 1999/2000, estimated private returns for wage earners aged 15-59 years for three levels of education: primary, secondary, and university. He regressed sex, age, and dummies for educational

\footnotetext{
${ }^{3}$ Although over time researchers have included more variables such as age, gender, occupation, location, and family background variables such as parent's education and occupation. However Psacharopoulos and Patrinos (2004) note that variables which are conditioned on education, such as occupation and firm size, should not be included in the model since they take away part of the impact of education on earnings.
} 
attainment on the log of real annual earnings with two OLS models: with and without cluster fixed effects (accounting for variations in local demand for labour) and found larger coefficients on education in the former ranging between 7-30 per cent. Appleton (2001) found conflicting results: for the 1992 returns at secondary were higher than at primary but the reverse for $1999 / 2000$. There was evidence for an increase in returns to education over time, though it was only the returns to primary that were statistically significant.

Studies which have investigated the returns to education using quantile regressions for developing countries (Patrinos et al. 2006; Kingdon and Söderbom 2007a) find that returns decrease with earnings. The explanation for the observed differences in outcomes is the complementarity between education and ability which is influenced by the education system and quality of education. In most studies marginal returns to education for women are higher than for men (Schultz 2003; Kingdon and Söderbom 2007b). This disparity implies that the supply of educated women is growing less than their demand: which mirrors the constraints faced by women in accessing education in most developing counties which induces higher returns for the successful ones.

Psacharopoulos and Patrinos (2004) highlight various challenges to estimating returns to education, including the limited sample coverage that normally is not a representative sample of the population. They note two methodological problems. First, researchers using the Mincerian framework consider the raw coefficients on education in the extended (dummy-form) function as the returns to education but these are more appropriately interpreted as wage effects because they do not take into account the cost of education. However, it is important to note that the Mincerian model assumes that opportunity cost is the only cost of education which is plausible for countries where government provides free education. The second problem is that many researchers include all possible independent variables they have in the dataset, yet variables that are conditional on the education level such as occupation, sector, and firm size tend to take away part of the effect of education on wages and should be excluded from the model.

\section{Theoretical framework}

The analysis in this study is based on the human capital framework developed by Mincer (1974). In this framework education is an investment of current resources for future earnings. Therefore, individuals choose an amount of schooling $(S)$ to maximize their expected present value of a stream of future earnings up to retirement at date $T$, net of the cost of education $\left(C_{s}\right)$. At the optimum schooling choice $(S)$, the present value $(P V)$ of the $S^{\text {th }}$ year of schooling will be equal to the cost of the $S^{\text {th }}$ year of schooling given the equilibrium:

$$
\sum_{t=1}^{T-S} \frac{Y_{S}-Y_{S-1}}{\left(1+r_{S}\right)^{t}}=Y_{S-1}+C_{S}
$$

Where $Y$ - is earnings and $r$ - is the internal rate of return.

If $T$ is large then Equation (1) can be rewritten as:

$$
\frac{Y_{S}-Y_{S-1}}{r_{S}}=Y_{S-1}+C_{S}
$$


If $C_{S}$ is small then Equation (2) can be written as:

$$
r_{S}=\frac{Y_{S}-Y_{S-1}}{Y_{S-1}} \approx \log Y_{S}-\log Y_{S-1}
$$

The expression in Equation (3) implies that the return to the $S^{\text {th }}$ year of schooling is approximately the difference in log earnings between leaving in the $S^{\text {th }}$ and at the $(S-1)^{\text {th }}$ year of schooling. Thus one would estimate the returns to $S$ by seeing how $\log$ earnings vary with $S$. Further assumptions are made to simplify the estimation of the returns to education. For instance $r_{s}$ is assumed to be constant, where $r=\Delta Y_{t} / h_{t} Y_{t}, Y_{t}$ is potential earnings and $b_{t}$ is the proportion of period $t$ spent acquiring human capital. Thus during schooling $h_{t}=1$ and $Y_{S}=Y_{o} e^{r s}$, meaning that individuals do not earn while in school. Mincer (1974) assumes that $h_{t}$ declines linearly with experience where $h_{t}=b_{0}-\left(b_{0} / T\right)_{t}$. Assuming that $Y_{0}$ can be captured as a linear function of characteristics $X$, such that $Y_{S}=Y_{0} e^{r s}=X \beta^{r s}$. We then write the expression for earnings after $x$ years of schooling as: $Y_{x}=Y_{0} e^{r s} \exp r\left[h_{0} x-\frac{h_{0}}{2 T} x^{2}\right]$. Taking the logarithm, $\log Y_{x}=\log Y_{0}+r S+r h_{0} x-\left(\frac{r h_{0}}{2 T}\right) x^{2}$. Since actual earnings are $Y_{x}=\left(1-h_{x}\right) Y_{x}$, we obtain the Mincer specification: $\log Y_{x}=X \beta+r S+r h_{0} x-\left(\frac{r h_{0}}{2 T}\right) x^{2}+\log \left(1-b_{x}\right)$, which translates to the empirical functional form of the human capital framework given as:

$$
\log w_{i}=X_{i} \beta+r S_{i}+\rho x_{i}+\gamma x_{i}^{2}+\varepsilon_{i}
$$

Where $w_{i}$ - is the level of earnings of individual $i$ such as per hour or month. $S_{i}-$ is the amount of schooling $x_{i}$ - is a measure of experience ${ }^{4}, X_{i}-$ is the vector of other variables assumed to affect earnings and $\varepsilon_{i}$ is the disturbance term representing other unobserved variables, assumed to be independent of $x_{i}, X_{i}$ and $S_{i}$. A quadratic term of experience is included to capture the concavity of the earnings profile.

Note that Mincer assumes the only cost of schooling is the foregone earnings, thus $r$ can be assumed as the private financial return to schooling and the effect of schooling on earnings. The private return is gross since it does not include a deduction of taxes on earnings.

\section{$4 \quad$ Empirical strategy}

Using the Mincerian human capital earnings framework the study estimates a pooled regression model; we pool data from two waves of the Uganda household panel survey of 2005/06 and 2009/10 for wage and self-employed workers:

$$
\ln \text { wage }_{i t}=\beta_{0}+\beta_{1 j} s c h_{i t}+\beta_{2 j} \exp _{i t}+\beta_{3 j} \exp _{i t}^{2}+\beta_{4 j} \text { fem }_{i t}+\beta_{5 j} y r_{i t}+\varepsilon_{i t}
$$

\footnotetext{
4 In the absence of a variable to capture experience, Mincer suggested use of potential experience which is equivalent to $A-(S+\sigma)$, where $A$ is age and $S$ is years of schooling (which begins at the age of six).
} 
Where $t$ is time period 1 and 2 , Inwage $_{i t}$ is $\log$ of calculated monthly wage for individual $i$ in period $t$ which we estimate separately for the two employment types denoted as $j$, so $j=1$ represents the wage-employees and $j=2$ represents the self-employed, $\beta_{0}$ is the intercept, $\beta_{1 j}$ - $\beta_{5 j}$ are parameters to be estimated, sch is a measure of years of schooling, exp measures potential experience which is age minus education minus six years, $\exp ^{2}$ is experience squared which is an indicator for an individual's earnings over lifetime, fem is dummy for female gender, $y r$ is year dummy, and $\varepsilon$ is the error term assumed to be normally distributed. In our model, we exclude all explanatory variables which are likely to be a channel through which education affects earnings such as sector of employment, occupation, residence, and firm size.

The study will investigate the non-linearity in returns to education by including a quadratic schooling term in the model and estimate the following model:

$$
\ln w a g e_{i t}=\beta_{0}+\beta_{1 j} s c h_{i t}+\beta_{2 j} s c h_{i t}^{2}+\beta_{3 j} \exp _{i t}+\beta_{4 j} \exp _{i t}^{2}+\beta_{5 j} f e m_{i t}+\beta_{6 j} y r_{i t}+\varepsilon_{i j}
$$

where $s c h^{2}$ is the square of years of schooling, if $\beta_{2 \mathrm{j}}$ is negative (positive) then there is concavity (convexity) in marginal returns to schooling.

If qualifications matter more than years of education such that the sixth year of education is significantly different from the seventh year (completed primary) one would use level of education attained rather than years attended. We therefore include dummies for each level of education which is synonymous with education qualification to test whether there is a jump in the returns to education from one level of education to another by estimating Equation (7):

$$
\begin{aligned}
& \ln \text { wage }_{i t}=\beta_{0}+\beta_{1 j} \text { prim }_{i t}+\beta_{2 j} \sec _{i t}+\beta_{3 j} d_{i t}+\beta_{4 j} \operatorname{deg}_{i t}+\beta_{5 j} \exp _{i t}+\beta_{6 j} \exp _{i t}^{2}+\beta_{7 j} \text { fem }_{i t} \\
& +\beta_{8 j} y r_{i t}+\varepsilon_{i}
\end{aligned}
$$

where prim refers to primary level education, sec to secondary level education, dip to diploma level education, and deg to degree level educational attainment. Individuals with uncompleted primary are the reference group. We also test the 'Sheepskin' effect which suggests a wage premium for completing the final year of each level of education by estimating the following model:

$$
\begin{aligned}
& \ln \text { wage }_{i t}=\beta_{0}+\beta_{1 j} e d u c_{i t}+\beta_{2 j} \operatorname{prim}_{i t}+\beta_{3 j} \sec _{i t}+\beta_{4 j} \operatorname{dip}_{i t}+\beta_{5 j} \operatorname{deg}_{i t}^{2} \\
& +\beta_{6 j} \exp _{i t}+\beta_{7 j} \exp _{i t}^{2}+\beta_{8 j} \text { fem }_{i t}+\beta_{9 j} y r_{i t}+\varepsilon_{i t}
\end{aligned}
$$

If $\beta_{i j}=0$ and either $\beta_{2 j}$ or $\beta_{3 j}$ or $\beta_{4 j}$ or $\beta_{5 j} \neq 0$ then there is evidence of the sheepskin effect implying that the returns to a year of education prior to attaining the education qualification is zero and it is only after an individual attains a credential (education qualification) that $\mathrm{s} / \mathrm{he}$ experiences an increase in wages.

We will further investigate individual heterogeneity by estimating returns to education along the earnings profile using the quantile regression method. Specifications (5-8) measure mean returns to education for an individual with mean earnings. However, returns could be heterogeneous across individuals especially along the earnings distribution. Such heterogeneity has implications for the inequality-reducing role of education and policy implications on investment in education. If the distribution of earnings is dispersed then the mean estimate may not be reliable, thus the need to consider quantile estimates particularly the median. The aim is to find out whether the influence of schooling on earnings varies along the distribution of the dependent variables. 
Workers at the high percentile will be regarded as the high-ability individuals and those at the low percentile as low-ability individuals. The following will be estimated:

$$
Q_{\tau}\left(w_{i j} / X_{i t}\right)=\alpha(\tau)+X_{i t}^{\prime} \beta(\tau)
$$

where $Q_{\tau}\left(w_{i t} / X_{i t}\right)$ denotes the $\tau^{t h}$ quantile of $\log$ wages on a vector of variables $\left(X_{i t}\right)$. If $\mathrm{q}_{0}(\tau)$ is the $\tau^{\text {th }}$ quantile of $w_{\text {in }}$, then $q_{0}(\tau)$ solves the following minimizing problem (Wooldridge 2010: 450):

$$
\min _{q \in \mathcal{R}} E\left\{\left(\tau 1\left[w_{i j}-q \geq 0\right]+(1-\tau) 1\left[w_{i j}-q<0\right] w_{i j}-q \mid\right\}\right.
$$

where 1[.] is the indicator function equal to one if the statement in brackets is true and zero otherwise. The check function or asymmetric absolute loss function can be expressed as:

$$
c_{\tau}(u)=(\tau 1[u \geq 0]+(1-\tau) 1[u<0])|u|=(\tau-1[u<0]) u
$$

The slope of the check function in Equation (11) is $\tau$ when $u>0$ and $-(1-\tau)$ when $u<0$ and undefined if $u=0$. If $\tau=0.5$ then $Q_{\tau}\left(w_{i t} \mid X_{i t}\right)$ will be the conditional median return to education.

Up to this point, we have assumed education is an exogenous variable. This is widely disputed, since it is not clear whether educated workers earn more because of their education or other unobserved factors such as ability or family background. When education is correlated with unobserved variables (omitted variables) then it is difficult to infer the casual effect of education on earnings. As noted by Card (2001), higher ability individuals may acquire more education and possibly benefit more from it thus causing an upward bias of OLS estimates. One of the solutions to the endogeneity problem is to use the instrumental variable method, which we estimate using the following earnings function:

$$
E\left[\ln w_{i t} / \gamma_{i t}\right]=\alpha+E\left(\beta s c h_{i t} / \gamma_{i t}^{\prime} \pi\right)+E\left(\varepsilon_{i t} / \gamma_{i t}\right)
$$

where $Z_{i t}$ are the instrumental variables which include: mother's and father's education that must satisfy the following orthogonality conditions:

$$
E\left[\alpha / \gamma_{i t}\right]=0 \quad E\left[\left(\beta_{i} / \tau_{i t}\right]=0 \quad E\left[\varepsilon_{i t} / \tau_{i t}\right]=0\right.
$$

And the instrumental variable affecting $s c h_{\text {it }}$ only through:

$$
E\left[s c h_{i t} / \tau_{i t}\right]=q_{i t}^{\prime} \pi
$$

where $\pi$ is a vector of reduced form coefficients and consequently the instrumental variable estimation will produce consistent results. In the estimations we will use the 2SLS estimator.

Since we estimate the returns to education on a sub-sample of individuals with reported earnings that are a non-random draw from our sample (as confirmed by the t-test for the sample means for two sub-samples-educated with earnings and educated without earnings), we re-estimate the returns to education while controlling for selection bias. Specifically, we employ the Heckman full information maximum likelihood model which estimates the selection model from a latent variable $Z^{*}$ in the first stage: 


$$
\begin{aligned}
& Z_{i t}^{*}=Y_{i t}^{\prime} \alpha+u_{i t} \\
& Z_{i t}=0 \quad \text { if } \quad Z_{i t}^{*} \leq 0 \\
& Z_{i t}=1 \quad \text { if } \quad Z_{i t}^{*}>0
\end{aligned}
$$

where $Z_{i t}$ is the participation variable equal to 1 if the individual is a wage-employee or selfemployed and 0 - otherwise. The $Y_{i t}$ is a vector of exclusion variables including; marital status, and number of children which we assume affect the reservation and not the market wage.

In the second stage the wage equation is modelled as:

$$
E\left(\ln w_{i t} / z_{i t}^{*}>0\right)=X_{i t}^{\prime} \beta+\lambda(\Gamma)+\varepsilon_{i t}
$$

where $\lambda=\frac{\phi\left(z_{i t}\right)}{\Phi\left(-\tau_{i t}\right)}$ is the inverse Mills ratio which is a monotonic decreasing function of the probability that an observation is selected into the sample, $\varphi$ is the density function and $\Phi$ the cumulative distribution function for a standard normal variable.

\section{$5 \quad$ Data sources and descriptive statistics}

\subsection{Data sources}

The study uses panel data from the 2005/06 Uganda National Household Survey (UNHS) and the 2009/10 Uganda National Panel Survey (UNPS) waves collected by the Uganda Bureau of Statistics, sourced from the World Bank databank (2014a, 2014b). The 2005/06 UNHS was conducted between May 2005 and April 2006, while the 2009/10 UNPS conducted between May 2009 and April 2010 is the first panel wave in a series of planned annual panel surveys in Uganda. The surveys are integrated with several modules which include: agriculture, community, household, market, and in addition the 2009/10 wave has the women module. We specifically use data from the household module for both waves which has relevant data on earnings, education, age, sex, marital status, children (below 18 years) in the household, residence (rural or urban), region, district, whether a household received non-labour income, and the value as well as parental background such as mother's and father's education and father's occupation. In both waves individuals reported earnings (in cash and kind equivalent) in Uganda shillings over varying time periods which we convert into US\$ equivalent as shown in Appendix Tables A1 and A2. In total the sample has 2,333 wage-employees and 848 self-employed individuals with reported earnings (after trimming the data) as displayed in Table 1.

\subsection{Descriptive statistics}

Our dependent variable is the logarithm of monthly earnings which we obtain by converting the different earnings reported in varying time periods into monthly earnings which was the most frequent period. Given that reported earnings are over many different periods as shown in Appendix Tables A1 and A2, we calculate a monthly wage in consideration of the reported days worked per month; for those who reported a daily wage and hours worked per day; for those who reported hourly pay. We note that hours worked per day and days worked per month were reported only in the 2005/06 wave. Consequently, we compute the average hours of work which is approximately eight hours (7.58) and average days worked per month, which is approximately 
19 days (18.85) which we use to estimate monthly wages for the 2009/10 wave where such data is missing. In case of individuals who reported hourly pay, their earnings were multiplied by the number of hours worked per day and days worked in a month, or used average hours or days for the 2009/10 wave. Similarly, for individuals who reported daily pay, their earnings were multiplied by the number of days worked in a month, or average days for the $2009 / 10$ wave. For individuals who reported weekly pay we multiplied their earnings by $52 / 12$ (some months have more than four weeks) while for individuals who reported pay for every two weeks or twice monthly the wage was multiplied by two to obtain the monthly pay.

Evident in these tables are the outliers such as the daily earnings for individuals in 2009/10 which are outrageously high and very low annual earnings in 2005/06. Since the data has outliers we trim one per cent at the top and bottom and present the summary statistics in Table 1. It is clear that the calculated monthly wage varies across waves with a general increase in wage over time and a higher monthly pay for wage-employees than the self-employed. For example, in the pooled data wage-employees earn 58 per cent more than the self-employed. We also note a wide dispersion between the mean and median wages for both types of workers, with the greatest variation among wage-employees. These statistics are surprising considering the fact that wages in the formal sector are supposed to be standardized, but we attribute the observed pattern to more workers in the private than public sector. For instance on average public sector workers earn US $\$ 128$ per month, while private sector workers earn US $\$ 65$ who form 80 per cent of the sample for wage-employees.

Over time the wages have increased with a greater percentage increase among the self-employed than wage-employees. Generally, there are fewer observations for self-employed individuals with reported earnings which could be as a result of the highly flexible wages in this sector, making it difficult for such workers to precisely report earnings or workers may not be willing to report low pay due to the stigma attached to poor remuneration. A comparison between reported earnings and calculated monthly earnings in Appendix Tables A1 and A2 shows dispersed earnings which we further analyse in Figure 1.

Table 1: Distribution of individuals with calculated monthly earnings

\begin{tabular}{|c|c|c|c|c|c|c|c|c|c|}
\hline & \multicolumn{3}{|c|}{ Pooled } & \multicolumn{3}{|c|}{$2005 / 06$} & \multicolumn{3}{|c|}{$2009 / 10$} \\
\hline & Obs & Mean & Median & Obs & Mean & Median & Obs & Mean & Median \\
\hline \multirow[t]{2}{*}{ Wage } & 2,333 & 67.92 & 38.02 & 1,276 & 60.37 & 29.23 & 1,057 & 77.04 & 45.15 \\
\hline & & (87.48) & & & (84.33) & & & (90.34) & \\
\hline \multirow[t]{2}{*}{ Self } & 848 & 43.25 & 22.55 & 561 & 38.05 & 18.55 & 287 & 53.42 & 28.52 \\
\hline & & (55.79) & & & (52.45) & & & $(60.62)$ & \\
\hline Total & 3,181 & & & 1,837 & & & 1,344 & & \\
\hline
\end{tabular}

Note: Earnings are reported in US\$ equivalent to Ugandan shillings (UGX/US\$) exchange rate of 1,779 in 2005/06 and 2,104 in 2009/10 (according to official statistics in the respective years) and standard deviation in parentheses.

Source: Authors' construction based on World Bank (2014a, 2014b).

In Figure 1, after trimming the data we compare reported monthly earnings with calculated monthly earnings, for workers who reported a daily and weekly pay to find out whether the distributions are similar using the Kennel density distribution among wage-employees. We observe similar distributions among the three types of earnings, depicting relatively higher earnings for those paid weekly and low earnings for individuals paid daily which mirrors the distribution in the raw data, where we notice higher pay rates for individuals paid weekly and lower pay rates for individuals paid daily. 
Figure 1: Calculated monthly earnings

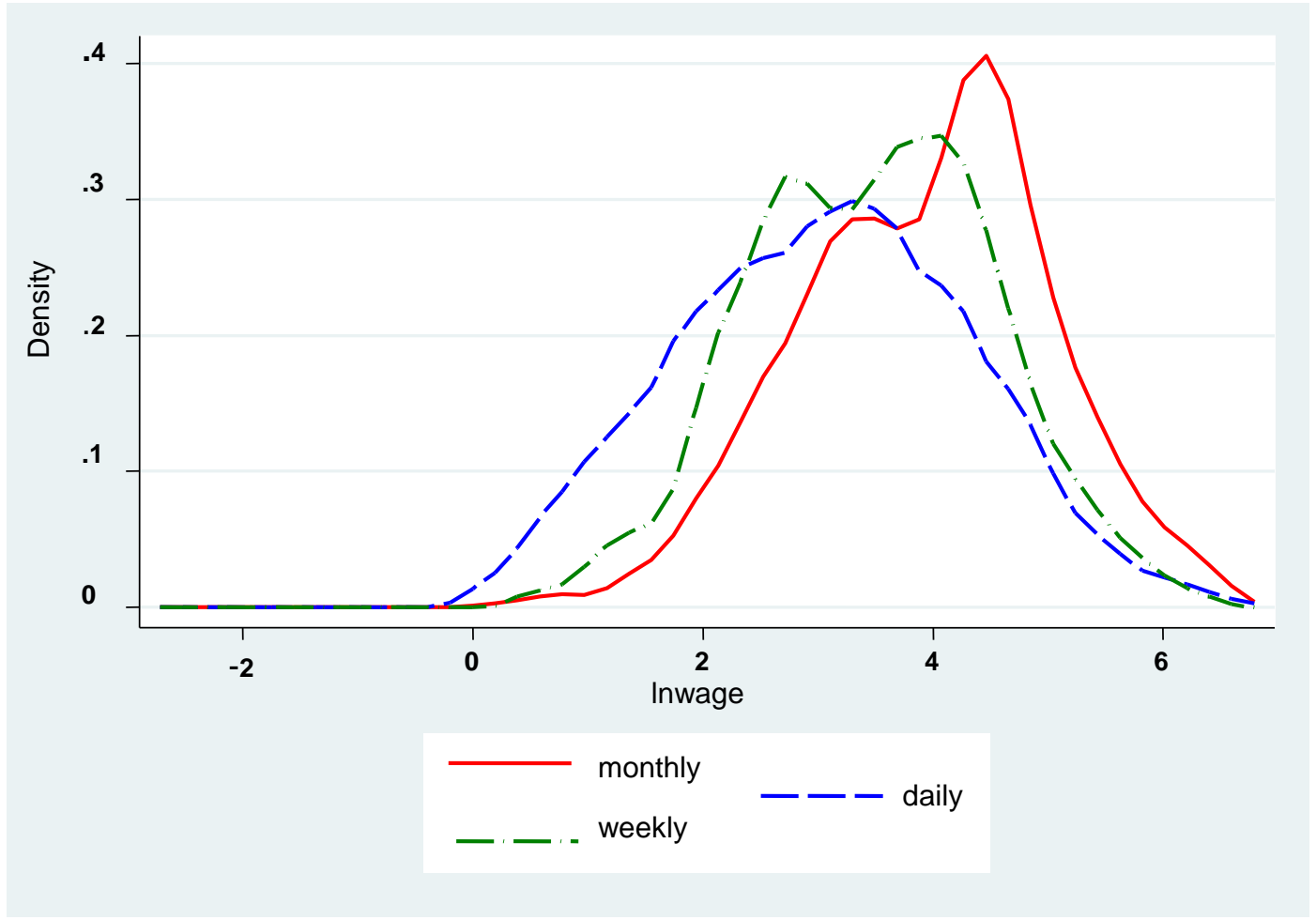

Notes: The figure shows the distribution of monthly earnings separated by reporting period.

Source: Authors' construction based on World Bank data (2014a, 2014b).

In Figure 2, we present the distribution of log earnings for both wage-employees and the selfemployed using a Kennel density distribution. The results are consistent with earlier observations where the highest earnings are amongst wage-employees who have a bimodal distribution and the lowest earnings are for the self-employed with relatively more spread earnings.

Figure 2: Distribution of log-earnings by employment type

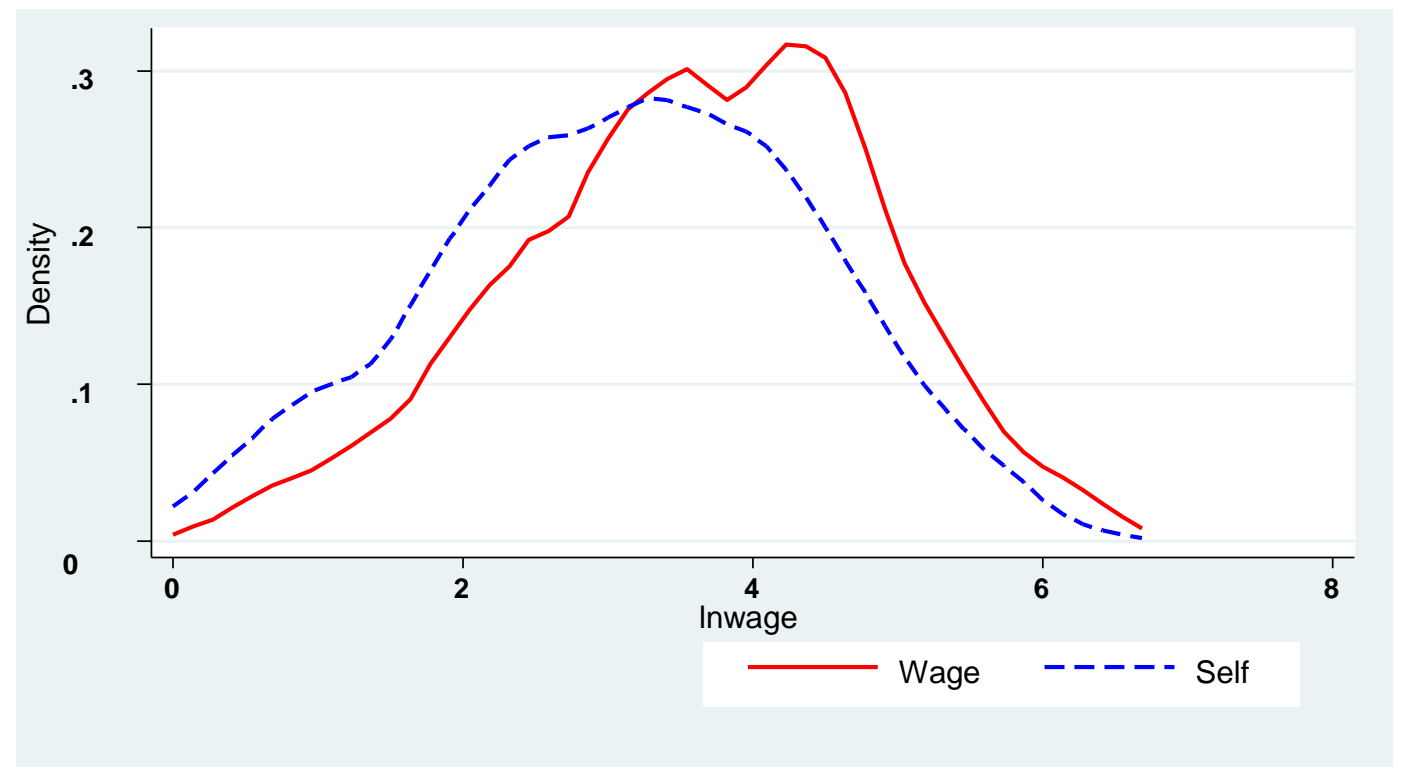

Source: Authors' construction based on World Bank (2014a, 2014b). 
We observe wage gaps by gender, residence, and age-group as illustrated in Appendix Tables A35. In Appendix Table A3, the statistics reveal a slightly wider gender wage gap in wage than selfemployment. For instance males earn 34 per cent more than females in wage-employment compared to males earning 24 per cent more than females in self-employment. We reckon that the observed gender wage gap is a result of lower education levels for women compared to men as noticed in the data, but we cannot rule out discrimination at the workplace. The distribution of monthly earnings for wage-employees and the self-employed by residence (rural/urban) is presented in Table A4. The rural-urban wage gap for wage-employees is similar to that for the self-employed. We find that workers in urban areas earn 90 per cent more than their counterparts in rural areas, which can be partly explained by differences in productivity. Table A5 presents the distribution of monthly earnings for wage-employees and the self-employed by age group, divided into the 'old' (30 years and above) and 'young' (less than 30 years) age group. We observe a wider wage gap between the young and the old in wage-employment than in selfemployment. For instance, an older worker earns 61 per cent more than a younger worker in wage-employment, while an older worker earns 36 per cent more than a younger worker in selfemployment. These differences in earnings by age could be due to accumulated human capital which increases the earnings of the older workers.

The summary statistics for the different explanatory variables are presented in Table 2 . The statistics suggest wage-employees are more schooled but relatively younger with less experience than the self-employed. Over time, average levels of education have increased for both types of workers, with the greatest increment among diploma holders in the case of wage-employees and holders of secondary school certificates for the self-employed. Also, we note more women are self- than wage-employed which is not surprising but could be signalling restricted entry of women into wage-employment. As expected, there is a greater concentration of wage than selfemployment in urban areas and Kampala (capital city), which perhaps is a result of the imbalance in economic development between rural and urban areas in Uganda.

Table 2: Summary statistics of key explanatory variables

\begin{tabular}{lllllll}
\hline \multirow{2}{*}{ Variable } & \multicolumn{3}{c}{ Wage-employees } & \multicolumn{3}{c}{ Self-employed } \\
\hline Education & Pooled & $2005 / 06$ & $2009 / 10$ & Pooled & $2005 / 06$ & $2009 / 10$ \\
Uncompleted & 0.39 & 7.89 & 9.06 & 7.29 & 7.06 & 7.76 \\
Primary & 0.38 & 0.43 & 0.33 & 0.51 & 0.53 & 0.46 \\
Secondary & 0.15 & 0.15 & 0.14 & 0.14 & 0.13 & 0.14 \\
Diploma & 0.32 & 0.30 & 0.33 & 0.25 & 0.24 & 0.27 \\
Degree & 0.11 & 0.08 & 0.14 & 0.08 & 0.08 & 0.08 \\
Experience & 0.04 & 0.03 & 0.05 & 0.02 & 0.02 & 0.04 \\
Age & 17.99 & 17.96 & 18.02 & 20.25 & 20.00 & 20.77 \\
Female & 32.13 & 31.94 & 32.38 & 33.18 & 33.06 & 33.41 \\
Urban & 0.32 & 0.33 & 0.32 & 0.41 & 0.39 & 0.45 \\
Married & 0.42 & 0.39 & 0.46 & 0.29 & 0.29 & 0.28 \\
Children & 0.57 & 0.60 & 0.52 & 0.63 & 0.63 & 0.62 \\
Non-labour income & 2.77 & 2.72 & 2.83 & 3.14 & 2.96 & 3.50 \\
Kampala & 0.29 & 0.42 & 0.11 & 0.37 & 0.46 & 0.20 \\
Father education & 0.18 & 0.17 & 0.18 & 0.08 & 0.09 & 0.07 \\
Mother education & 0.20 & 0.18 & 0.22 & 0.12 & 0.12 & 0.12 \\
\hline Source Authors'cons & 0.07 & 0.07 & 0.08 & 0.03 & 0.02 & 0.03 \\
\hline
\end{tabular}

Source: Authors' construction based on World Bank data (2014a, 2014b). 


\subsection{Returns to an additional year of schooling}

First, as highlighted in the empirical strategy we estimate returns to an additional year of schooling, separately for wage-employees and the self-employed when education is considered exogenous and present the results in Table 3. Later we address the problem of endogeneity and selection bias. A Chow test cannot reject the hypothesis that returns to education are equal in the two sectors. Therefore, for both sectors an individual's extra year of schooling is associated with an increase in earnings of 16 per cent. The results are plausible for Uganda because they signal similar human productivity in these two sectors of employment and in support of the human capital theory rather than the signalling theory, since the effects of education to the selfemployed can only be human capital effects considering that there are no information asymmetries when a person is self-employed (Brown and Sessions 2004).

We also find evidence of a concave age-earnings relationship which is stronger for wage than self-employment. These results indicate that earnings for wage-employees increase at a decreasing rate, over a worker's lifetime which could be because of restricted entry age and retirement age policy that is less applicable in self-employment. In addition, the results show lower earnings premium to females than males for both sectors with a greater gender gap in wage-employment, which is consistent with the descriptive statistics. Similarly, the year dummy shows a higher increment in earnings over time for self- than wage-employment, which was observed in the descriptive statistics.

Table 3: Returns to an additional year of schooling by employment type

\begin{tabular}{|c|c|c|c|c|}
\hline \multicolumn{5}{|c|}{ Dependent variable: log monthly wage } \\
\hline & \multicolumn{2}{|c|}{ Wage } & \multicolumn{2}{|c|}{ Self } \\
\hline & Coef & SE & Coef & SE \\
\hline Years of schooling & $0.161^{* \star \star}$ & 0.005 & $0.157^{\star \star \star}$ & 0.009 \\
\hline Experience & $0.043^{\star \star *}$ & 0.007 & $0.033^{* *}$ & 0.013 \\
\hline Experience squared & $-0.001^{* * *}$ & 0.000 & $-0.001^{*}$ & 0.000 \\
\hline Female & $-0.355^{\star * *}$ & 0.047 & $-0.248^{\star \star \star}$ & 0.080 \\
\hline Year dummy & $0.275^{\star \star \star}$ & 0.039 & $0.409^{\star * *}$ & 0.084 \\
\hline Intercept & $1.855^{\star \star *}$ & 0.085 & $1.653^{* * *}$ & 0.166 \\
\hline R-squared & 0.379 & & 0.277 & \\
\hline Observations & 2,033 & & 696 & \\
\hline
\end{tabular}

Note: Standard errors (SE) are Clustered standard errors, ${ }^{*} p<0.10,{ }^{* *} p<0.05,{ }^{* * *} p<0.01$.

Source: Authors' own construction based on World Bank (2014a, 2014b).

To test for non-linearity in the schooling-earnings function, we include a quadratic term for education in the estimation. We find the returns to education are weakly convex for wageemployees and linear for the self-employed after fitting the predicted coefficients as illustrated in Figure 3; the coefficient estimates are provided in Appendix Table A6. Therefore a linear model would be a good approximation for the effect of education on earnings for both worker types. 
Figure 3: Change in predicted wages due to changes in education with a quadratic term

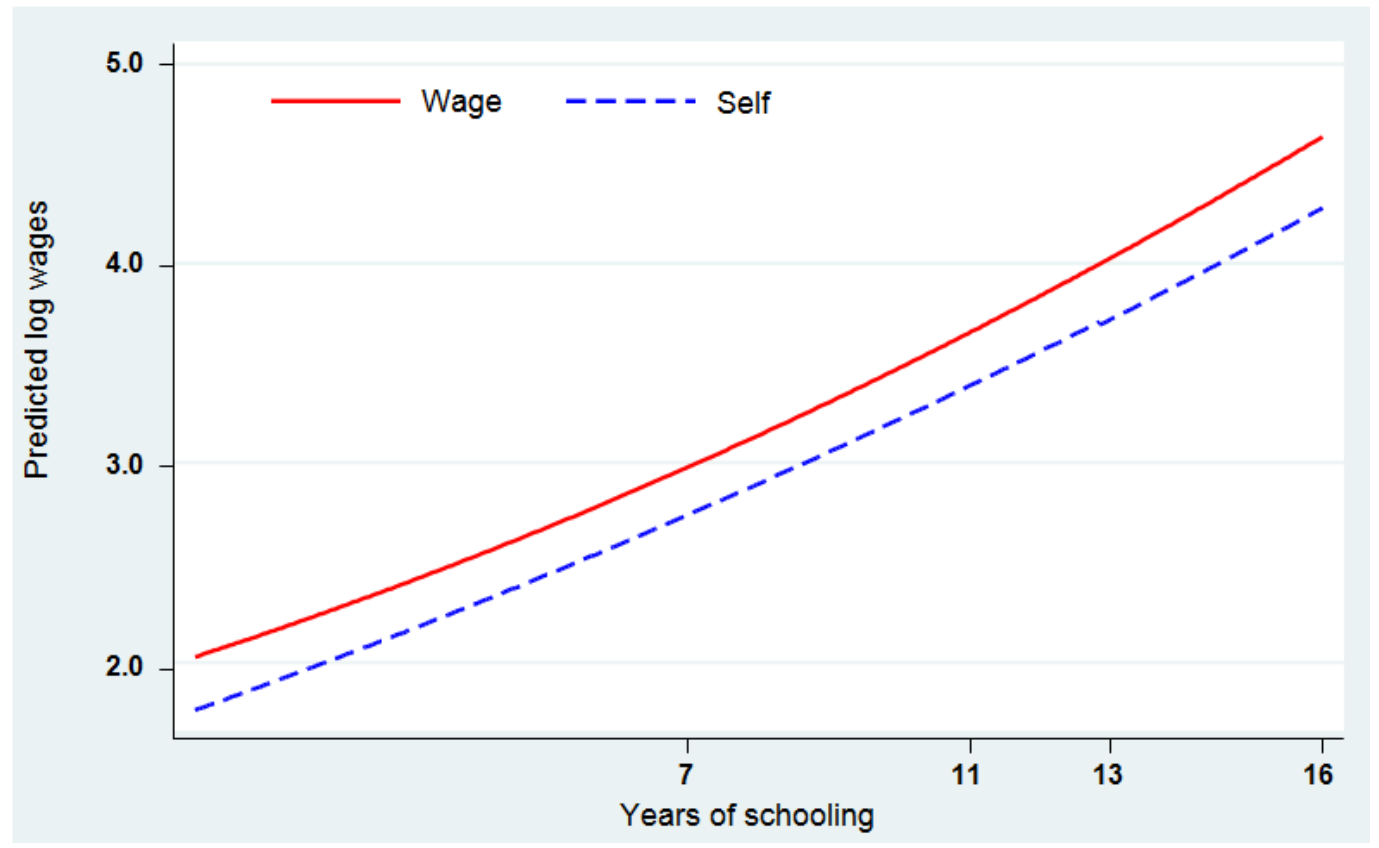

Source: Authors' construction based on World Bank (2014a, 2014b).

\subsection{Trend of returns to education over time}

During the study period 2005-10, the average years of schooling increased as presented in the descriptive statistics (refer to Table 2). According to theory, this increase is expected to result in a reduction in the returns to education, if we assume that the relative demand for educated workers remained constant. We find our results are consistent with theory showing a decrease in returns to education over time as shown by the flatter (less steep) slope of the schooling-earnings profile in 2009 than in 2005 in Figure 4 and 5. Noticeably, for both wage and self-employment the intercept has increased over time, with the increment larger for the latter which suggests that the earnings have increased but for reasons other than those captured in our model. We reason that this increase in earnings could have resulted from the robust economic growth Uganda has enjoyed for over two decades which is expected to result in increased wages. However, our results are in contrast with Appleton's (2001) findings of an increase in returns to education to workers in wage-employment in Uganda between 1992 and 2000; although he reports that it was only the returns to primary education which were statistically significant. We think this contrast is due to differences in average levels of educational attainment which were much lower in the periods preceding the implementation of the UPE in 1997 and USE in 2007. 
Figure 4: Change in predicted wages by education over time for wage-employees

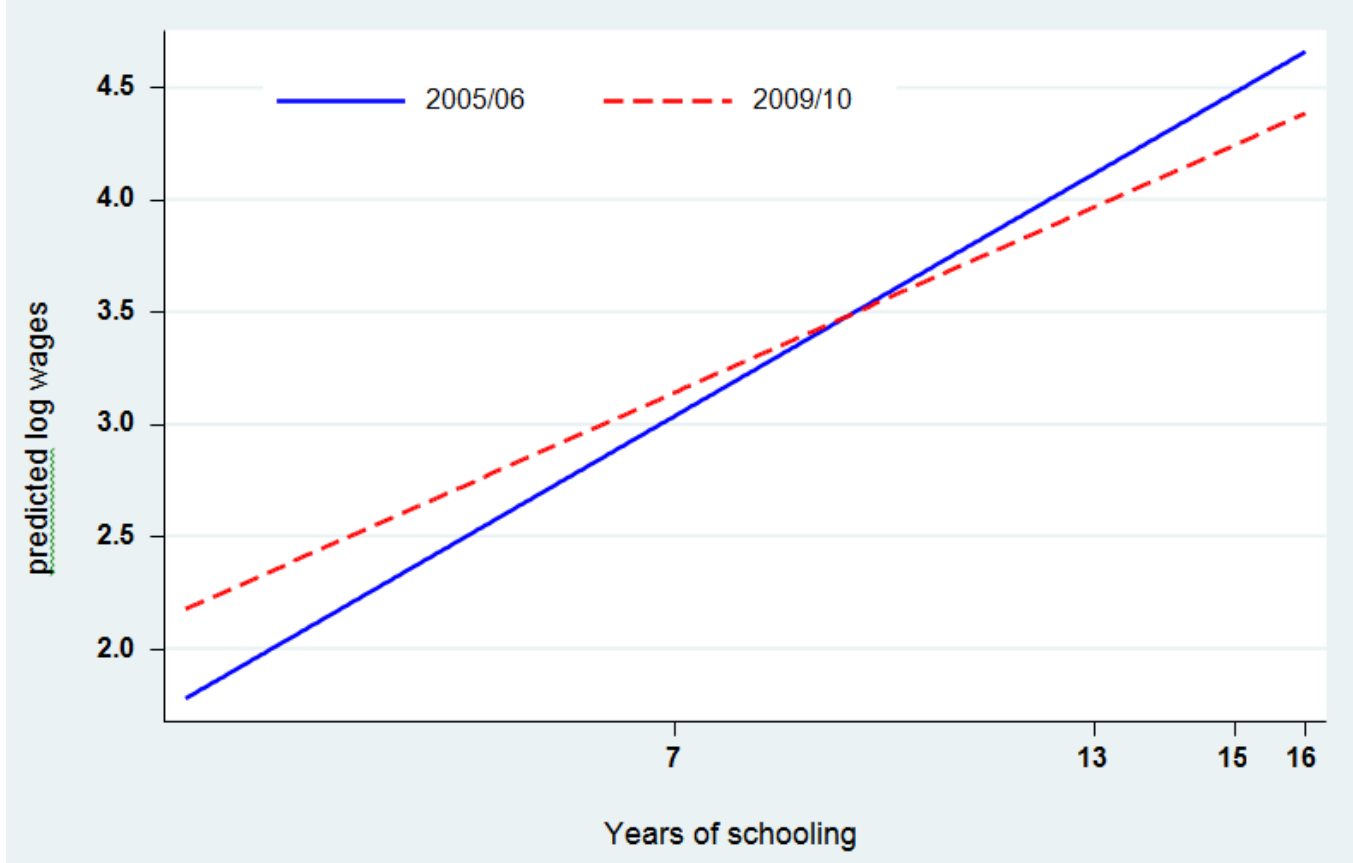

Source: Authors' construction based on World Bank (2014a, 2014b).

Figure 5: Change in predicted wages by education over time for the self-employed

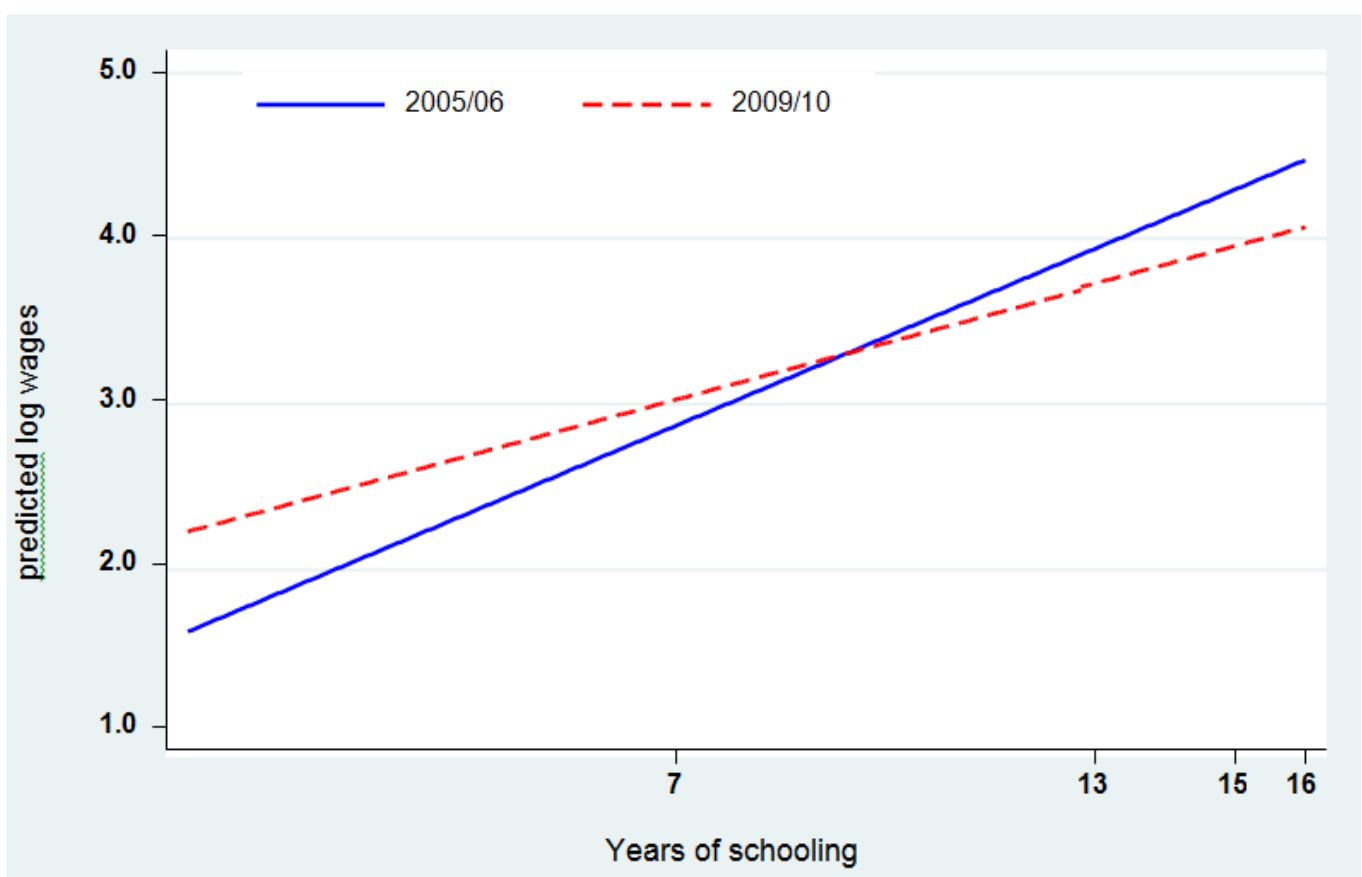

Source: Authors' construction based on World Bank (2014a, 2014b). 


\subsection{Returns to education qualifications}

We re-estimate the Mincerian model but replace years of education with dummies for education qualification (Equation 7) to test for non-linearities in returns to education along the education profile. The results are presented in Table 4 with panel A showing marginal returns for each qualification and panel B illustrating the change in marginal returns between two successive education qualifications. The change in marginal returns at each education qualification is obtained by calculating the difference in returns between two successive education qualifications, divided by the number of years of education for the qualification considered. For example, in the case of secondary education, we calculate the difference in the marginal returns at secondary and primary and divide it by six (number of years required to obtain an ' $A$ ' level certificate), while for degree education we calculate the change in returns between secondary and degree and divide by three (duration of a degree in humanities).

The results in Table 4 (Panel B) show convex returns to education qualifications for wageemployees and in contrast concave returns to the self-employed. Our results for wage-employees are similar to Söderbom et al. (2005) for Kenya and Tanzania and Sandefur et al. (2006) for Ghana and Tanzania who found convex returns to education for wage employees. The results for the self-employed are in contrast with Sandefur et al.'s (2006) findings of convex returns to education for the self-employed in Ghana, Tanzania, and Ethiopia. The difference in the shape of the education qualifications-earnings curve between wage-employees and the self-employed in our case, could be a mirror of differences in skills demand in the two sectors; formal and informal with lower skills demands in the latter. We note low returns at primary level of education which are weak for the self-employed. These results could be signalling low levels of productivity for workers with primary education which results in low remuneration. This casts doubt on the impact of primary education on an individual's productivity and employability especially in self-employment in Uganda. We are aware that without primary education, an individual cannot attain the successive levels of education, but we are more concerned with the many that may not be able to progress to the next level (see the descriptive statistics in Table 2).

Surprisingly, we find higher returns to education at secondary and diploma level for the selfemployed compared to wage-employees, but find higher returns to degree education for wage than self-employment. This may be due to a combination of demand and supply factors, where on the demand side the skills for self-employment are lower than wage-employment and on the supply side these individuals (especially diploma holders) possess relevant practical skills required at the work place.

Consistent with the findings for an additional year of education, the returns at all education qualifications have decreased over time with the reduction increasing with levels of education for both worker types. We note that the returns to education have declined more in self- than wageemployment. For example, an individual in wage-employment with secondary education experienced a decline in marginal returns to education of 33 percentage points, while the counterpart in self-employment their earnings declined by 49 percentage points. The variation in the rate of decline in marginal returns to education is greatest with individuals holding degrees, where those in wage-employment experienced a decline of 50 percentage points and the selfemployed suffered a decline in marginal returns to education of 96 percentage points. Though we have data for only two waves, we argue that since the waves have a difference of four years between them, these results could be a good indication of the trend in returns to education over time. Therefore, we reason that these results could be signalling the lack of relevant jobs to absorb more qualified workers (especially those with post-primary education), who eventually 
accept jobs that require lower qualifications, which could be a result of the supply of educated individuals growing more than their demand.

Table 4: Returns to education qualifications by employment type

\begin{tabular}{|c|c|c|c|c|c|c|}
\hline \multicolumn{7}{|c|}{ Dependent variable: log monthly earnings } \\
\hline \multirow[t]{2}{*}{ Panel A: coefficient estimates } & \multicolumn{3}{|c|}{ Wage-employees } & \multicolumn{3}{|c|}{ Self-employed } \\
\hline & Pooled & $2005 / 06$ & $2009 / 10$ & Pooled & $2005 / 06$ & $2009 / 10$ \\
\hline \multirow[t]{2}{*}{ Primary } & $0.340^{* * *}$ & $0.439^{* * *}$ & $0.173^{*}$ & $0.246^{\star}$ & 0.239 & 0.157 \\
\hline & $(0.074)$ & $(0.100)$ & $(0.096)$ & $(0.129)$ & $(0.157)$ & $(0.226)$ \\
\hline \multirow[t]{2}{*}{ Secondary } & $1.042^{\star \star *}$ & $1.175^{\star * \star}$ & $0.841^{* * *}$ & $1.076^{\star \star \star}$ & $1.219^{\star \star *}$ & $0.730^{\star \star *}$ \\
\hline & $(0.054)$ & $(0.073)$ & $(0.070)$ & $(0.102)$ & $(0.122)$ & $(0.183)$ \\
\hline \multirow[t]{2}{*}{ Diploma } & $1.621^{\star \star \star}$ & $1.847^{\star \star \star}$ & $1.366^{\star \star \star}$ & $1.729^{\star \star \star}$ & $1.986^{\star \star \star}$ & $1.186^{\star \star \star}$ \\
\hline & $(0.065)$ & $(0.088)$ & $(0.080)$ & $(0.123)$ & $(0.125)$ & $(0.249)$ \\
\hline \multirow[t]{2}{*}{ Degree } & $2.280^{\star * \star}$ & $2.511^{* * *}$ & $2.006^{\star * *}$ & $1.727^{\star \star \star}$ & $2.182^{\star \star *}$ & $1.222^{\star * \star}$ \\
\hline & $(0.105)$ & $(0.140)$ & $(0.143)$ & $(0.230)$ & $(0.315)$ & $(0.267)$ \\
\hline \multirow[t]{2}{*}{ Intercept } & $2.581^{* * *}$ & $2.583^{\star \star *}$ & $2.842^{* * *}$ & $2.377^{\star \star *}$ & $2.427^{\star * *}$ & $2.839^{* * *}$ \\
\hline & $(0.080)$ & $(0.114)$ & $(0.102)$ & $(0.154)$ & $(0.180)$ & $(0.267)$ \\
\hline \multicolumn{7}{|l|}{ Panel B: marginal returns } \\
\hline \multirow[t]{2}{*}{ Primary } & $0.048^{\star \star \star}$ & $0.063^{\star * *}$ & $0.025^{*}$ & $0.035^{\star}$ & 0.034 & 0.022 \\
\hline & $(0.010)$ & $(0.014)$ & $(0.014)$ & $(0.018)$ & $(0.022)$ & $(0.032)$ \\
\hline \multirow[t]{2}{*}{ Secondary } & $0.117^{\star \star \star}$ & $0.123^{\star * *}$ & $0.111^{* * *}$ & $0.138^{* * *}$ & $0.163^{* * *}$ & $0.095^{\star *}$ \\
\hline & $(0.012)$ & $(0.016)$ & $(0.016)$ & $(0.024)$ & $(0.029)$ & $(0.041)$ \\
\hline \multirow[t]{2}{*}{ Diploma } & $0.289^{\star \star \star}$ & $0.336^{\star \star \star}$ & $0.263^{* \star *}$ & $0.326^{\star \star \star}$ & $0.383^{\star * \star}$ & $0.228^{*}$ \\
\hline & $(0.032)$ & $(0.043)$ & $(0.040)$ & $(0.068)$ & $(0.072)$ & $(0.130)$ \\
\hline \multirow[t]{2}{*}{ Degree } & $0.413^{* \star *}$ & $0.445^{\star * *}$ & $0.388^{* * *}$ & $0.217^{\star * \star}$ & $0.321^{* * *}$ & $0.164^{*}$ \\
\hline & $(0.035)$ & $(0.046)$ & $(0.048)$ & $(0.079)$ & $(0.106)$ & $(0.094)$ \\
\hline R-squared & 0.356 & 0.339 & 0.349 & 0.283 & 0.328 & 0.136 \\
\hline Observations & 2,033 & 1,128 & 905 & 696 & 472 & 224 \\
\hline
\end{tabular}

Notes: Clustered standard errors in parentheses, ${ }^{*} p<0.10,{ }^{* *} p<0.05$, ${ }^{* *} p<0.01$, uncompleted primary is the reference group.

Source: Authors' construction based on World Bank (2014a, 2014b).

We also tested for the sheepskin effect by estimating Equation (8) but found no evidence of this effect, since we continue to observe significant returns to each additional year of education and no significant returns to education qualifications except for the degree holders in wageemployment as shown in Table 5. We argue that our results for the degree holders in wageemployment are inconclusive, because we are not able to observe individuals who join university but fail to complete since individuals reported years of education up to senior six ('A' level). The years of reported diploma and degree education qualifications are assumed. 
Table 5: Returns to additional year of education and education qualifications-Sheepskin effect

\begin{tabular}{|c|c|c|c|c|}
\hline \multicolumn{5}{|c|}{ Dependent variable: log monthly wage } \\
\hline & \multicolumn{2}{|c|}{ Wage-employees } & \multicolumn{2}{|c|}{ Self-employed } \\
\hline & Coef & SE & Coef & SE \\
\hline Years of education & $0.146^{\star * *}$ & 0.015 & $0.138^{* \star *}$ & 0.027 \\
\hline Primary & -0.068 & 0.086 & -0.152 & 0.149 \\
\hline Secondary & 0.065 & 0.065 & 0.186 & 0.201 \\
\hline Diploma & 0.052 & 0.177 & 0.236 & 0.317 \\
\hline Degree & $0.564^{\star \star *}$ & 0.210 & 0.114 & 0.390 \\
\hline Intercept & $1.941^{\star \star \star}$ & 0.102 & $1.746^{* \star *}$ & 0.198 \\
\hline R-squared & 0.385 & & 0.309 & \\
\hline Observations & 2,033 & & 696 & \\
\hline
\end{tabular}

Note: Clustered standard errors in parentheses, ${ }^{*} p<0.10,{ }^{* *} p<0.05,{ }^{* * *} p<0.01$.

Source: Authors' construction based on World Bank (2014a, 2014b).

In Figure 6 we demonstrate the marginal returns to each education qualification for wageemployees. The figure shows a large increase in marginal returns at diploma which is consistent with the results in Table 5 and the fitted line shows that the marginal returns are convex.

Figure 6: Marginal returns to education qualifications for wage-employees

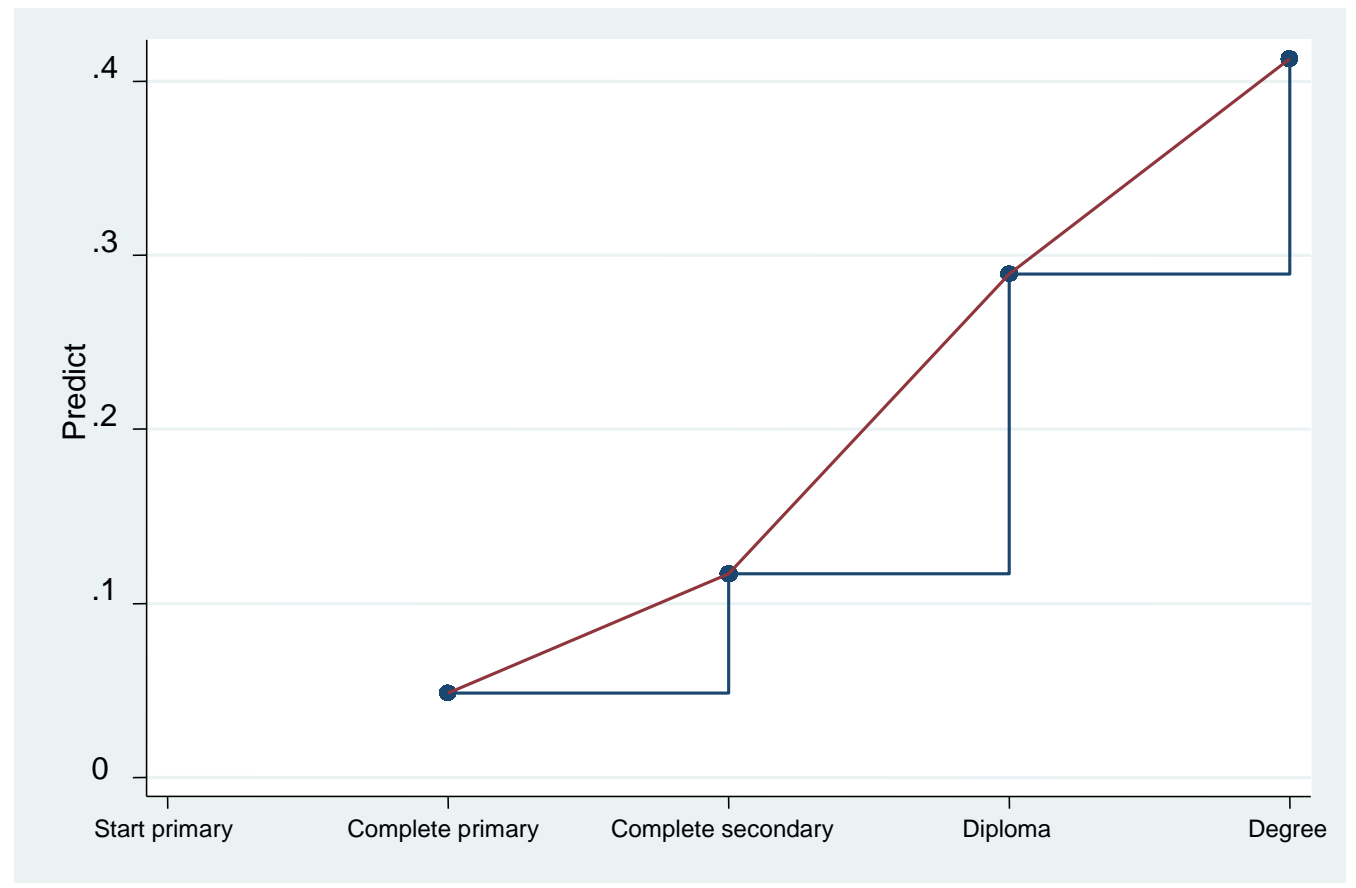

Source: Authors' construction based on World Bank (2014a, 2014b).

A similar diagram for marginal returns to education qualifications for the self-employed is presented in Figure 7. In this case, we observe that the marginal returns are highest at diploma and decline at degree which provides evidence for concave returns to education for the selfemployed. These results could be signalling low skill demand in this sector and individuals with degree education are likely to be over-qualified for tasks in self-employment in Uganda. 
Figure 7: Marginal returns to education qualifications for the self-employed

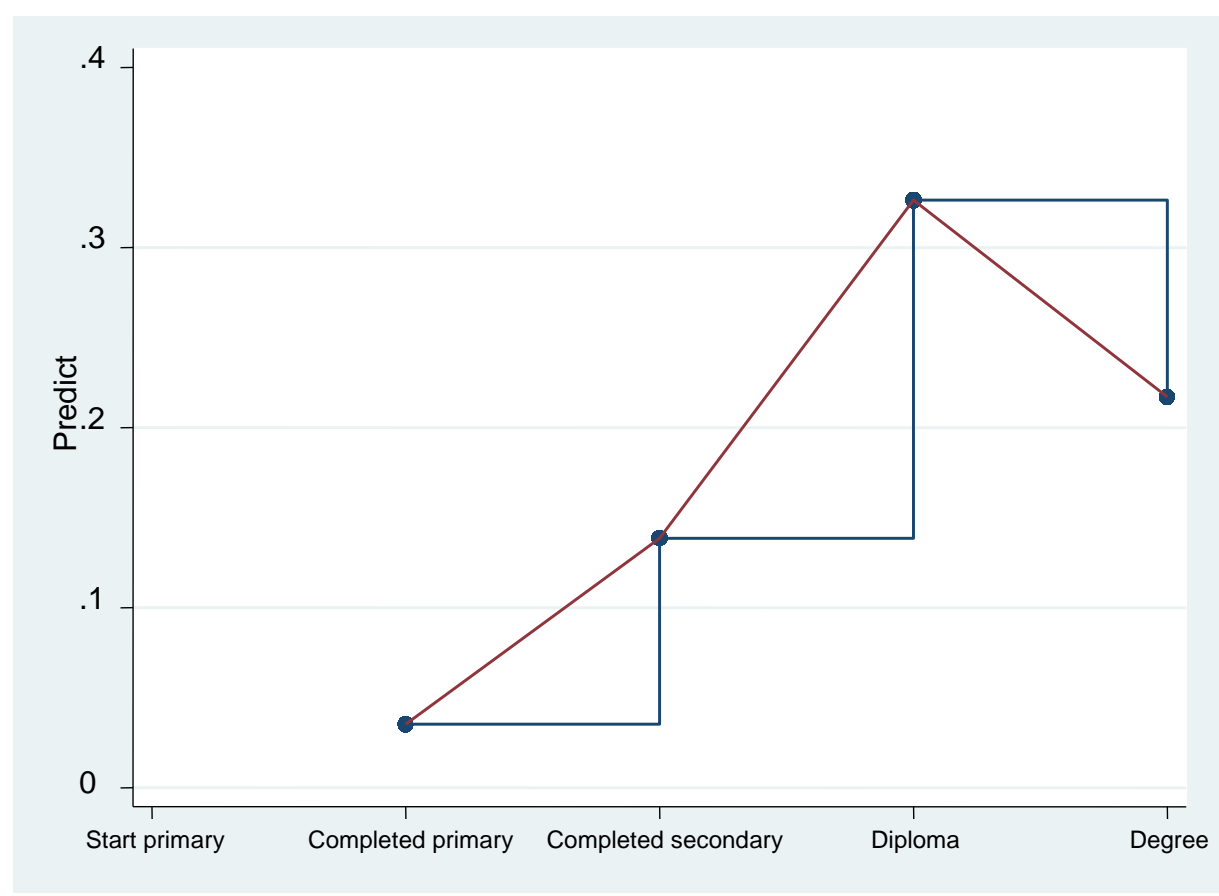

Source: Authors' construction based on World Bank (2014a, 2014b).

\subsection{Quantile regressions}

The Mincerian model assumes individuals are homogenous and provides an estimate for an average individual, but individuals may be heterogeneous with different rates of return to education along the earnings profile. We test for this heterogeneity along the earnings profile by estimating quantile regressions, which are flexible and allow the returns in each quantile to be independent from another. As illustrated in Table 6, the returns to education along the earnings distribution vary for both wage and self-employment. Overall, the earnings premium reduces with quantiles implying that education is more beneficial to individuals at the lower quantiles than for those at the upper quantile. The explanation for these outcomes is that education and ability are substitutes where individuals with less education, but of high ability have higher marginal returns to education. Given these results, we conclude that investment in education in Uganda is more beneficial to the less able (poor) than the more able (rich) individuals and therefore can be effective in reducing income inequality. Notably, the mean and median returns to education for both types of workers are similar and thus the OLS results are a fair estimate.

Table 6: Quantile regression by employment type

\begin{tabular}{|c|c|c|c|c|c|c|c|c|c|c|}
\hline & \multicolumn{2}{|c|}{0.1} & \multicolumn{2}{|c|}{0.25} & \multicolumn{2}{|c|}{0.5} & \multicolumn{2}{|c|}{0.75} & \multicolumn{2}{|c|}{0.9} \\
\hline & Wage & Self & Wage & Self & Wage & Self & Wage & Self & Wage & Self \\
\hline & $0.177^{\star * *}$ & $0.188^{* \star *}$ & $0.184^{\star \star *}$ & $0.184^{\star \star *}$ & $0.163^{\star *}$ & $0.162^{\star \star \star}$ & $0.150^{\star \star \star}$ & $0.141^{* * *}$ & $0.144^{\star * *}$ & $0.131^{\star * *}$ \\
\hline & $(0.012)$ & $(0.017)$ & $(0.005)$ & $(0.016)$ & $(0.005)$ & $(0.012)$ & $(0.006)$ & $(0.016)$ & $(0.006)$ & $(0.010)$ \\
\hline Pseudo $\mathrm{R}^{2}$ & 0.209 & 0.164 & 0.245 & 0.178 & 0.249 & 0.200 & 0.199 & 0.167 & 0.180 & 0.170 \\
\hline Observations & 2,033 & 696 & 2,033 & 696 & 2,033 & 696 & 2,033 & 696 & 2,033 & 696 \\
\hline
\end{tabular}

Notes: Bootstrapped standard errors in parentheses, ${ }^{*} p<0.10,{ }^{* *} p<0.05,{ }^{* * *} p<0.01$, other controls include; experience, experience squared, female, year dummy, and an interaction term between year and education.

Source: Authors' construction based on World Bank (2014a, 2014b). 


\subsection{Controlling for endogeneity}

As earlier discussed, it is not possible to infer causality of education on earnings because of the likelihood of the unobservables in the wage equation (e.g. ability) correlating with earnings. To address this endogeneity or omitted variable bias problem we re-estimate the wage equations using the 2SLS estimator with father's education as the instrument in the model for wageemployees, and both mother's and father's education in the model for self-employment. ${ }^{5}$ The earnings premium increases to 25 per cent for the wage-employees and to 21 per cent for the self-employed as shown in Table 7. These results are consistent with many studies that find a downward bias in OLS estimates for returns to an additional year of schooling (Card 1999; Psacharopolous and Patrinos 2004; Girma and Kedir 2005; Söderbom et al. 2005). Several reasons are given for higher instrumental variable (IV) returns to education which include: invalidity of instruments, attenuation bias arising from measurement errors in reported schooling levels, and IV estimates regarded as LATE. ${ }^{6}$ We checked for the validity of instruments by running a first stage regression diagnostics and obtained an F-statistic of 102.21 (wage-employees model), and in the case of the self-employed we used two instruments; mother's and father's education which are valid according to the Sagan test. We therefore conclude that there could be attenuation bias and the effect of LATE which biases the results. We tested for endogeneity of education using the Hausman test (Hausman 1978), which rejected the hypothesis that all our variables in the model are exogenous, implying that the OLS estimates are biased.

Table 7: Returns to an additional year of schooling when schooling is endogenous

\begin{tabular}{|c|c|c|c|c|}
\hline \multicolumn{5}{|c|}{ Dependent variable: log monthly wage } \\
\hline & \multicolumn{2}{|c|}{ Wage } & \multicolumn{2}{|c|}{ Self } \\
\hline & Coef & SE & Coef & SE \\
\hline Years of schooling & $0.254^{\star * *}$ & 0.023 & $0.207^{\star * \star}$ & 0.042 \\
\hline Experience & $0.032^{\star \star *}$ & 0.009 & 0.023 & 0.017 \\
\hline Experience squared & $-0.000^{*}$ & 0.000 & -0.000 & 0.000 \\
\hline Female & $-0.372^{\star \star *}$ & 0.057 & $-0.291^{* * *}$ & 0.089 \\
\hline Year dummy & $0.155^{\star \star}$ & 0.067 & $0.457^{\star \star \star}$ & 0.112 \\
\hline Intercept & $1.114^{\star \star \star}$ & 0.251 & $1.344^{\star \star \star}$ & 0.413 \\
\hline R-squared & 0.328 & & 0.336 & \\
\hline Observations & 1,392 & & 522 & \\
\hline
\end{tabular}

Notes: SE are cluster standard errors, ${ }^{*} p<0.10,{ }^{* *} p<0.05,{ }^{* * *} p<0.01$.

Source: Authors' construction based on World Bank (2014a, 2014b).

\subsection{Selectivity corrected returns to education}

Given that we estimate returns to education on a sub-sample of individuals who are not a random draw, the OLS estimates are likely to be biased. To correct this bias we re-estimate wage equations for the wage and self-employed using the Heckman full information maximum likelihood model, with the number of children and marital status as the exclusion restriction and the results are presented in Table 8. We find evidence of selection bias for the returns to wageemployees and reject the hypotheses of no correlation between the error term in the outcome

\footnotetext{
5 These instruments may not be valid if parental education is correlated with the error term in the earnings model.

${ }^{6}$ LATE provides estimates for individuals affected by the instrument (Angrist and Pischke 2009).
} 
and selection equations. We find the error terms are negatively correlated which is consistent with theory; individuals with a higher reservation wage are not observed in the wage equation for wage-employees. With regard to the self-employed, we find no evidence of selection bias and thus the OLS estimates are not biased by selectivity.

Table 8: Selectivity corrected returns to education

\begin{tabular}{|c|c|c|c|c|}
\hline \multicolumn{5}{|c|}{ Dependent variable: log monthly wage } \\
\hline & \multicolumn{2}{|c|}{ Wage } & \multicolumn{2}{|c|}{ Self } \\
\hline & Coef & SE & Coef & SE \\
\hline Years of schooling & $0.156^{* \star \star}$ & 0.005 & $0.155^{\star \star \star}$ & 0.009 \\
\hline Experience & $0.039^{* \star *}$ & 0.007 & $0.027^{* *}$ & 0.014 \\
\hline Experience squared & $-0.001^{* * *}$ & 0.000 & $-0.000^{*}$ & 0.000 \\
\hline Female & $-0.329^{\star * \star}$ & 0.050 & $-0.238^{* * *}$ & 0.080 \\
\hline Year dummy & $0.283^{* \star *}$ & 0.040 & $0.417^{\star \star \star}$ & 0.084 \\
\hline Inverse Mills ratio & $-0.823^{* * *}$ & 0.193 & -0.449 & 0.370 \\
\hline Intercept & $3.236^{* \star *}$ & 0.344 & $2.727^{\star \star \star}$ & 0.929 \\
\hline Observations & 17,351 & & 17,499 & \\
\hline
\end{tabular}

Notes: SE are cluster standard errors, ${ }^{*} p<0.10,{ }^{* *} p<0.05,{ }^{* * *} p<0.01$.

Source: Authors' construction based on World Bank (2014a, 2014b).

\section{$7 \quad$ Conclusion and policy implications}

This paper has analysed the differences in marginal private returns to education for wageemployees and the self-employed using the Mincerian framework with pooled regression models. We have not taken advantage of the panel element of our data because our key variable of interest; education is time invariant. In addition, we have not addressed the problem of attrition bias because of data limitations (too few waves and observations).

In the descriptive statistics, we observe a wider gender gap among wage-employees than the selfemployed. We attribute these differences to low levels of education among females which is evident in the data (where females have six mean years of schooling while males have seven mean years of schooling), rather than discrimination at workplace, although we cannot rule out the latter in some situations. As an area of future research, one could further investigate this scenario by decomposing the gender wage gap to gain insight in the likely factors influencing the observed wage gap.

We find similar marginal private returns to an additional year of schooling for wage-employees and the self-employed, with each extra year of schooling associated with a rise in wages of 16 per cent. Thus more schooling induces more earnings for a worker. Though, we note that we are only able to observe a correlation between education and earnings not a causal relationship, since we are unable to observe similar individuals with and without specified levels of education to infer the casual relationship between education and earnings.

These results are encouraging, suggesting that education is equally rewarding in the less-preferred informal sector (because of the low wages and poor working conditions in this sector) which employs two-thirds of Uganda's labour force. Nonetheless, when we investigate the shape of the education-earnings profile for the two types of workers by including a quadratic term of education, we find returns for the wage-employees are weakly convex but for the self-employed 
they are linear and a linear model is a good approximation of the effect of education on earnings in Uganda. In contrast, we find the marginal returns to education qualifications are convex for wage-employees and concave for the self-employed. The policy implication of our results depends on whether employers consider years of schooling or credentials. If employers consider credentials (which are plausible in Uganda's case) then higher levels of education are associated with higher returns for wage-employees but for the self-employed the returns decline after diploma education. We reason that these results suggest that individuals with post-diploma education are overqualified for tasks in self-employment.

Another key finding in this paper is the reduction of marginal private returns to education over time. Our results are consistent with theory, which predicts a decline in marginal returns when the levels of educational attainment increase with constant relative demand for each level. Lastly, we find marginal private returns to education decrease with quantile, which suggests that the less able (poor) individuals at the lower earnings distribution for both worker types have higher marginal private returns to education. These results are encouraging, because investment in education can reduce income inequality as it moves individuals at the lower earnings profile more than those at the upper earnings profile along the earnings distribution. Therefore, investment in education in Uganda is income-equalizing.

In conclusion, we find high marginal private returns to education in Uganda which implies that investment in education in Uganda is still viable and attractive. We propose continued investment in education both at the micro and macro level, even though we have not accounted for the externalities derived from education to put up a strong case for investment at the macrolevel, we believe the private returns are high enough to motivate the Government of Uganda to invest more in education. With regard to returns decreasing with quantile, the results signal that education and ability are substitutes, yet they are supposed to be complementary. The possible explanation for the link between education and ability in Uganda could be related to the quality and type of formal education provided, which perhaps does not adequately nurture an individual's innate ability. In this regard, we propose a review of the education curriculum with the aim of developing a curriculum which advances an individual's innate ability. Finally, the convex marginal returns to education qualifications for wage-employees suggest that higher levels of education would induce higher wages for individuals in wage-employment; though the returns are concave for the self-employed, highest at diploma level. This indicates increased demand for higher skills in the two sectors with degree education inducing higher wages only in wage-employment. Therefore, on the supply-side, we propose targeted investment in education especially at tertiary level to match the structure and functioning of the labour market in Uganda, in order to improve the pay-off from investing in education. For instance formal education should impart skills which match the demands for employment not only in the formal but also in the informal sector. Alternatively, on the demand side, there is need to expand the formal sector and encourage the formalization of the informal sector to absorb the increasing number of university graduates in the country.

\section{References}

Angrist, J., and J. Pischke (2009). Mostly Harmless Econometrics: An Empiricists Companion. Princeton, NJ: Princeton University Press.

Appleton, S. (2000). 'Education and Health at Household Level in sub-Saharan Africa'. Working Paper 33. Cambridge, MA: Harvard University, Center for International Development. 
Appleton, S. (2001). 'Education, Incomes and Poverty in Uganda in the 1990s'. Research Paper 01/22. Nottingham: University of Nottingham, Centre for Research in Economic Development and International Trade.

Becker, G.S. (1962). 'Investment in Human Capital: A Theoretical Analysis'. The Journal of Political Economy, 70(5, part 2: Investment in Human Beings): 9-49.

Brown, S., and J. Sessions (2004). 'Signalling and Screening'. In G. Johnes, and J. Johnes (eds), International Handbook on the Economics of Education. Cheltenham: Edward Elgar Publishing Limited.

Card, D. (1999) 'The Causal Effect of Education on Earnings'. In O. Ashenfelter, and D. Card (eds), Handbook of Labour Eonomics, volume 3. Amsterdam: Elsevier.

Card, D. (2001). 'Estimating the Return to Schooling: Progress on Some Persistent Econometric Problems'. Econometrica, 69(5): 1127-60.

Fasih, T., G. Kingdon, H.A. Patrinos, C. Salkellariou, and M. Söderbom (2012). 'Heterogeneous Returns to Education in the Labour Market'. Policy Research Working Paper 6170. Washington, DC: World Bank.

Girma, S., and A.M. Kedir (2005). 'Heterogeneity in Returns to Schooling: Econometric Evidence from Ethiopia'. International Conference on African Development Archives, Paper 92. Kalamazoo, MI: Western Michigan University.

Hausman, J.A. (1978). 'Specification Test in Econometrics'. Econometrica, 46(6): 1251-271.

Heckman, J., L. Lochner, and P. Todd (2006). 'Earnings Function, Rates of Return and Treatment Effects, the Mincer Equation and Beyond'. In E. Hanushek, and F. Welch (eds), Handbook of Economics of Education. Amsterdam: Elsevier.

Kerr, A., and S. Quinn (2010). 'Returns to Education in Tanzania: Exploiting a Natural Experiment'. Paper presented in the Centre for the Study of African Economies Conference on Economic Development in Africa, 21-23 March 2010, St Catherine's College, Oxford, UK.

Kingdon, G., and M. Söderbom (2007a). Education Skills and Labour Market Outcomes: Evidence from Ghana'. Draft Copy.

Kingdon, G., and M. Söderbom (2007b). 'Education Skills and Labour Market Outcomes: Evidence from Pakistan'. Draft Copy.

Koenker, R., and G. Bassett Jr. (1978). 'Regression Quantiles'. Econometrica, 46(1): 33-50.

Leyaro, V., P. Twumasi Baffour, O. Morrissey, and T. Owens (2012). 'Determinants of Urban Labour Earnings in Tanzania, 2000-06'. Preliminary Paper for Labour Market Dynamics in Times of Crisis in Africa, Project Workshop. Oxford: University of Oxford.

Mincer, J.A. (1974). Schooling, Experiences and Earnings. New York: Columbia University Press.

Patrinos, H.A., C. Ridao-Cano, and C. Sakellariou (2006). 'Estimating the Returns to Education: Accounting for Heterogeneity in Ability'. Policy Research Working Paper 4040. Washington, DC: World Bank.

Psacharopoulous, G., and H.A. Patrinos (2004). 'Returns to Investment in Education: A Further Update'. Education Economics, 12(2): 111-34.

Quinn, S., and F. Teal (2008). 'Private Sector Development and Income Dynamics: A Panel Study of the Tanzanian Labour Market'. Working Paper. Oxford: Centre for the Study of African Economies. 
Rankin, N., J. Sandefur, and F. Teal (2010). Learning and Earnings in Africa: Where Are the Returns to Education High?' Working Paper. Oxford: Centre for the Study of African Economies.

Sandefur, J., P. Serneels, and Francis. Teal (2006). 'African Poverty through the Lens of Labor Economics: Earnings and Mobility in Three Countries'. Working Paper 060. Oxford: University of Oxford, Global Poverty Research Group.

Schultz, P. (2003). 'Evidence of Returns to Schooling in Africa from Household Surveys: Monitoring and Restructuring the Market for Education'. Discussion Paper 875. New Haven, CT: Yale University, Economic Growth Centre.

Söderbom M., F. Teal, A. Wambugu, and G. Kahyarara (2005). 'The Dynamics of Returns to Education in Kenyan and Tanzanian Manufacturing'. Working Paper. Oxford: Global Poverty Research Group.

Spence, M. (1973). 'Job Market Signalling'. The Quarterly Journal of Economics, 87(3): 355-74.

Uganda Bureau of Statistics (2010). 'Uganda National Household Survey Report (2009/2010)'. Report. Kampala: Uganda Bureau of Statistics.

Wooldridge, J. (2010). Econometric Analysis of Cross Section and Panel Data. Second Edition.

World Bank (2014a). '2005/06 Uganda National Household Survey Data'. Databank. Washington, DC: World Bank.

World Bank (2014b). '2009/10 Uganda National Panel Survey Data'. Databank. Washington, DC: World Bank. 


\section{Appendix}

Table A1: Reported earnings for wage-employees

\begin{tabular}{|c|c|c|c|c|c|c|}
\hline \multirow[b]{3}{*}{ Period } & \multicolumn{3}{|c|}{$2005 / 06$} & \multicolumn{3}{|c|}{$2009 / 10$} \\
\hline & \multicolumn{2}{|c|}{ Reported } & \multirow{2}{*}{$\begin{array}{c}\text { Calculated monthly } \\
\text { wage } \\
\text { Mean (US\$) }\end{array}$} & \multicolumn{2}{|c|}{ Reported } & \multirow{2}{*}{$\begin{array}{c}\text { Calculated monthly } \\
\text { wage } \\
\text { Mean (US\$) }\end{array}$} \\
\hline & Obs & Mean (US\$) & & Obs & $\begin{array}{l}\text { Mean } \\
\text { (US\$) }\end{array}$ & \\
\hline Hourly & 13 & 8.80 & 412.6 & 3 & 48.79 & $7,416.98$ \\
\hline Daily & 586 & 2.08 & 38.69 & 302 & 3.64 & 69.11 \\
\hline Weekly & 105 & 9.69 & 42.02 & 100 & 15.07 & 65.3 \\
\hline Fortnight & 15 & 26.16 & 52.32 & & & \\
\hline Monthly & 588 & 102.67 & 102.67 & 628 & 107.41 & 107.41 \\
\hline Quarterly & 4 & 697.80 & 232.6 & & & \\
\hline Yearly & 3 & 103.04 & 8.59 & & & \\
\hline Other & & & & 37 & 33.13 & 70.36 \\
\hline Total & 1,314 & & & 1,070 & & \\
\hline
\end{tabular}

Notes: Earnings are reported in US\$ equivalent to UGX/US\$ exchange rate of 1,779 in 2005/06 and 2,104 in $2009 / 10$ (according to official statistics in the respective years).

Source: Authors' construction based on World Bank (2014a, 2014b).

Table A2: Reported earnings for the self-employed

\begin{tabular}{|c|c|c|c|c|c|c|}
\hline \multirow[b]{3}{*}{ Period } & \multicolumn{2}{|c|}{$2005 / 06$} & \multicolumn{3}{|c|}{$2009 / 10$} & \multirow{3}{*}{$\begin{array}{c}\text { Calculated monthly } \\
\text { wage } \\
\text { Mean (US\$) }\end{array}$} \\
\hline & \multicolumn{2}{|c|}{ Reported } & \multirow{2}{*}{$\begin{array}{l}\text { Calculated monthly } \\
\text { wage } \\
\text { Mean (US\$) }\end{array}$} & \multicolumn{2}{|c|}{ Reported } & \\
\hline & Obs & $\begin{array}{l}\text { Mean } \\
\text { (US\$) }\end{array}$ & & Obs & $\begin{array}{l}\text { Mean } \\
\text { (US\$) }\end{array}$ & \\
\hline Hourly & 7 & 0.50 & 20.21 & 1 & 0.47 & 64.64 \\
\hline Daily & 301 & 1.99 & 20.64 & 74 & 2.77 & 47.06 \\
\hline Weekly & 45 & 19.65 & 85.16 & 40 & 12.56 & 50.24 \\
\hline Fortnight & 14 & 10.83 & 21.66 & & & \\
\hline Monthly & 200 & 72.10 & 72.1 & 141 & 76.16 & 76.16 \\
\hline Quarterly & 5 & 90.13 & 30.74 & & & \\
\hline Yearly & 1 & 50.58 & 4.21 & & & \\
\hline Other & & & & 41 & 104.87 & 96.87 \\
\hline Total & 573 & & & 297 & & \\
\hline
\end{tabular}

Notes: Earnings are reported in US dollars equivalent to UGX/US\$ exchange rate of 1,779 in 2005/06 and 2,104 in 2009/10 (according to official statistics in the respective years).

Source: Authors' construction based on World Bank (2014a, 2014b). 
Table A3: Distribution of monthly earnings by gender

\begin{tabular}{lcccccc}
\hline & \multicolumn{3}{c}{ Wage-employees } & \multicolumn{3}{c}{ Self-employed } \\
& Obs & Mean & Median & Obs & Mean & Median \\
\hline Females & 751 & 55.04 & 25.29 & 350 & 38.12 & 19.01 \\
& & $(80.34)$ & & & $(51.32)$ & \\
Males & 1,582 & 74.04 & 45.15 & 499 & 46.86 & 25.29 \\
& & & & $(58.51)$ & \\
\hline
\end{tabular}

Notes: Standard deviation in parentheses.

Source: Authors' construction based on World Bank (2014a, 2014b).

Table A4: Distribution of monthly earnings by residence

\begin{tabular}{lcccccc}
\hline & \multicolumn{3}{c}{ Wage-employees } & \multicolumn{3}{c}{ Self-employed } \\
& Obs & Mean & Median & Obs & Mean & Median \\
\hline Urban & 992 & 93.54 & 59.13 & 241 & 65.45 & 40.40 \\
& & $(105.04)$ & & & $(70.16)$ & \\
Rural & 1,341 & 48.98 & 25.29 & 607 & 34.44 & 16.86 \\
& & & & $(46.12)$ & \\
\hline
\end{tabular}

Notes: Standard deviation in parentheses.

Source: Authors' construction based on World Bank (2014a, 2014b).

Table A5: Distribution of monthly earnings by age group

\begin{tabular}{lllllll}
\hline & \multicolumn{3}{c}{ Wage-employees } & \multicolumn{3}{c}{ Self-employed } \\
& Obs & Mean & Median & Obs & Mean & Median \\
\hline \multirow{2}{*}{ Old } & 1,245 & 82.47 & 48.90 & 475 & 49.01 & 23.76 \\
& & $(99.35)$ & & & $(63.68)$ & \\
\multirow{2}{*}{ Young } & 1,088 & $\begin{array}{l}51.28 \\
\text { (67.85) }\end{array}$ & 28.10 & 371 & 35.92 & 22.48 \\
& & & & $(42.70)$ \\
\hline
\end{tabular}

Notes: Standard deviation in parentheses.

Source: Authors' construction based on World Bank (2014a, 2014b). 
Table A6: Marginal returns to education with quadratic term for schooling

\begin{tabular}{|c|c|c|}
\hline \multicolumn{3}{|c|}{ Dependent variable: log monthly wage } \\
\hline & Wage & Self \\
\hline \multirow[t]{2}{*}{ Years of schooling } & $0.115^{\star \star \star}$ & $0.134^{\star * \star}$ \\
\hline & $(0.024)$ & $(0.045)$ \\
\hline \multirow[t]{2}{*}{ Schooling squared } & $0.003^{\star *}$ & 0.001 \\
\hline & $(0.001)$ & $(0.002)$ \\
\hline \multirow[t]{2}{*}{ Experience } & $0.043^{* * *}$ & $0.036^{* *}$ \\
\hline & $(0.007)$ & $(0.015)$ \\
\hline \multirow[t]{2}{*}{ Experience squared } & $-0.001^{* * *}$ & $-0.001^{*}$ \\
\hline & $(0.000)$ & $(0.000)$ \\
\hline \multirow[t]{2}{*}{ Female } & $-0.367^{* \star *}$ & $-0.281^{* * *}$ \\
\hline & $(0.047)$ & $(0.086)$ \\
\hline \multirow[t]{2}{*}{ Year dummy } & $0.275^{\star \star \star}$ & $0.352^{* * *}$ \\
\hline & $(0.039)$ & $(0.086)$ \\
\hline \multirow[t]{2}{*}{ Intercept } & $2.027^{* * *}$ & $1.764^{* * *}$ \\
\hline & $(0.124)$ & $(0.247)$ \\
\hline R-squared & 0.380 & 0.277 \\
\hline Observations & 2,033 & 697 \\
\hline
\end{tabular}

Notes: Clustered standard errors in parentheses, ${ }^{*} p<0.10,{ }^{* *} p<0.05,{ }^{* * *} p<0.01$.

Source: Authors' construction based on World Bank (2014a, 2014b). 